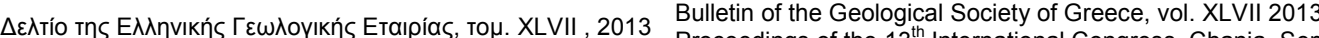

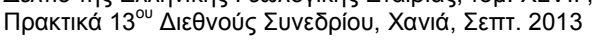

\title{
NEOTECTONIC ANALYSIS, ACTIVE STRESS FIELD AND ACTIVE FAULTS SEISMIC HAZARD ASSESSMENT IN WESTERN CRETE
}

\author{
Mountrakis D. ${ }^{1}$, Kilias A. ${ }^{1}$, Pavlaki A. ${ }^{1}$, Fassoulas C. ${ }^{2}$, Thomaidou E. ${ }^{1}$, Papa- \\ zachos $\mathrm{C}^{3}{ }^{3}$, Papaioannou $C^{4}{ }^{4}$, Roumelioti $Z_{.}{ }^{3}$, Benetatos $C^{3}{ }^{3}$ and Vamvakaris \\ D. ${ }^{3}$ \\ ${ }^{1}$ Aristotle University of Thessaloniki, Department of Geology \\ ${ }^{2}$ University of Crete, Natural History Museum \\ ${ }^{3}$ Aristotle University of Thessaloniki, Department of Geophysics \\ ${ }^{4}$ Institute of Engineering Seismology and Earthquake Engineering
}

\begin{abstract}
Within the framework of this study the complicated fault system of Western Crete was napped in detail and its kinematic and dynamic setting was analysed in order to distinguish 13 major active and possible active fault zones, the seismic potential of which was assessed. Moreover, kinematic data and striations were used to estimate the corresponding stress field geometry. Two stress phases were recognized: $1^{\text {st }}$ the $N-S$ extension phase $\left(D_{I}\right)$ in Mid-Upper Miocene to Lower Pliocene times forming $E-W$ normal faults that bound the Neogene basins; $2^{\text {nd }}$ the $E$ - $W$ extension phase $\left(D_{2}\right)$ in Late Pliocene-recent times forming N-S trending active normal faults. Smaller, mainly NE-SW trending faults, with significant strike-slip component, indicate a kinematic compatibility to the $D_{2}$ phase, acting as transfer faults between larger $N-S$ fault zones. The faults were incorporated in a detailed seismic hazard analysis together with the available seismological data, involving both probabilistic and deterministic approaches, for seismic hazard assessment of several selected sites (municipalities).
\end{abstract}

Key words: Active deformation, seismotectonics, probabilistic approach.

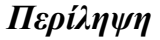

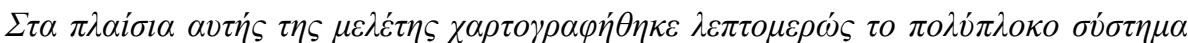

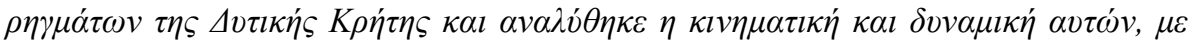

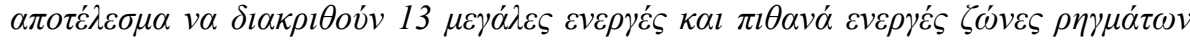

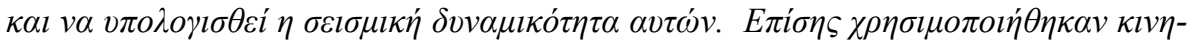

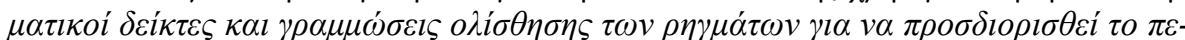

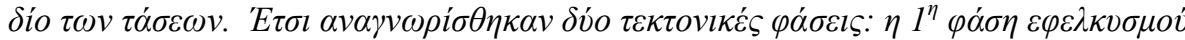

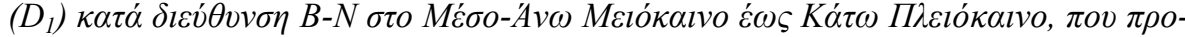

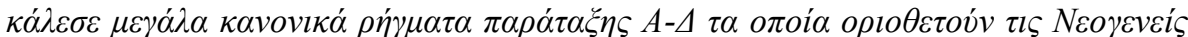

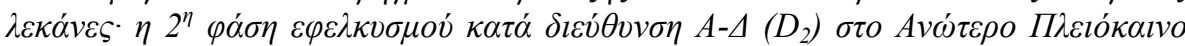

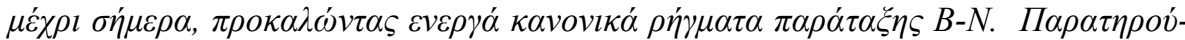

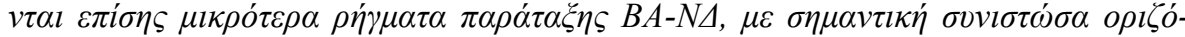

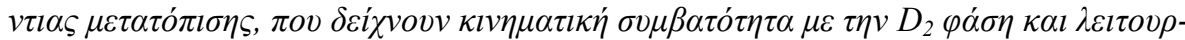




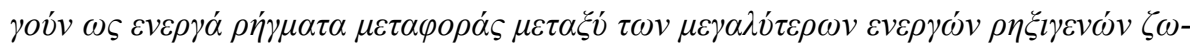

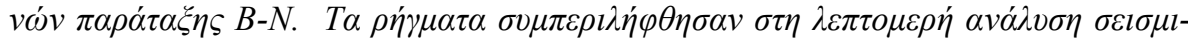

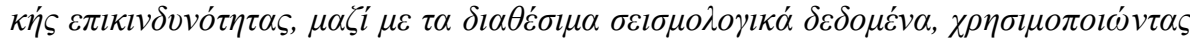

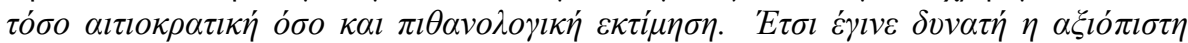

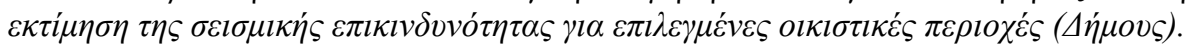

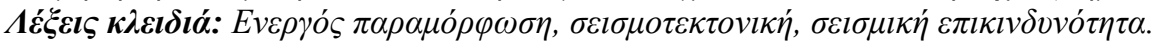

\section{Introduction}

The island of Crete is situated in a fore-arc position above the active northward-directed subduction zone of the African plate beneath the Aegean lithosphere, but the seismotectonic features of the broader Aegean area are controlled by the complicated geodynamic interaction of the Aegean, Anatolian and Eastern Mediterranean lithospheres (Papazachos et al 2000). Additionaly, Crete is a structurally complicated area been strongly affected by the Alpine orogenic processes from Jurassic to present day, due to plate convergence of Eurasian and African plates and the subduction of the Tethyan oceanic crust (Bonneau 1994, Mountrakis 2006, Kilias et al 2010). Nappes stacking and compression alternate with extension, nappes collapse and exhumation of deep crustal rocks (Seidel et al 1982, Bonneau 1984, Kilias et al 1994, Fassoulas et al 1994, Jolivet et al 1996). The active deformation in Crete is revealed by the creation of new as well as the reactivation of older major faults and the occurrence of strong shallow earthquakes.

Within the framework of this study the complicated fault system of Western Crete was mapped in detail and its kinematic and dynamic setting was analysed, in order to distinguish the major active, possible and geological (inactive) fault zones. The field study was completed by the analysis of fault-slip data recognized along the main fault zones. For the calculations we employed the slickenlines orientations and fault plane data, as well as kinematic indicators to determine the slip vector and the sense of movement. Furthermore, other geological criteria were used to distinguish fault generations and different tectonic events. These results were elaborated together with the available seismological data in order to develop a seismic hazard evaluation for selected areas. For the seismic hazard analysis, both probabilistic and deterministic approaches have been used.

\section{Neotectonic Analysis. Active Stress Field}

The geological structure of the Crete island consists of a complicated nappes pile been stacked successively during the Alpine orogenic processes from Jurassic to Miocene times. The major compressional regime which has determined the evolution of the nappes stacking, with a SSW sense of movement, took place in Oligocene-Lower Miocene times. Compression and nappes stacking were followed during Lower-Middle Miocene by a N-S collapse, tectonic thinning and extensional exhumation of the tectonic lower nappes in a series of tectonic windows (Fassoulas et al 1994, Kilias et al 1994). During this period the first Neogene basins of the island were formed, often bordered by syn-sedimentary normal boundary faults. The extensional tectonic regime after Middle Miocene is characterized by an initial N-S sub-horizontal extension and younger neotectonic faults (Mercier et al 1989).

A detailed study of the brittle neotectonic deformation in western Crete has been realized in the framework of a large-scale seismotectonic survey for the creation of a revised neotectonic map (fig. 1) in a scale of 1:50.000 (Mountrakis et al 2012). Two distinctive stress phases were recognized, corresponding to two main brittle tectonic events in Neogene-Quaternary. The first $\mathrm{D}_{1}$ tectonic event took place from Middle/Upper Miocene to Upper Pliocene as it affects the basins sediments of Miocene and Pliocene age, but not the younger Quaternary deposits. The major normal faults in Western Crete of E-W strike, which in some cases locally deviate to ENE-WSW and ESE-WNW, have been formed during this $\mathrm{D}_{1}$ event. They dip mainly to the North at high angle and correspond to the initial boundary fault zones of the Neogene basins of Crete and particularly

$\underline{\text { XLVII, No } 2-583}$ 


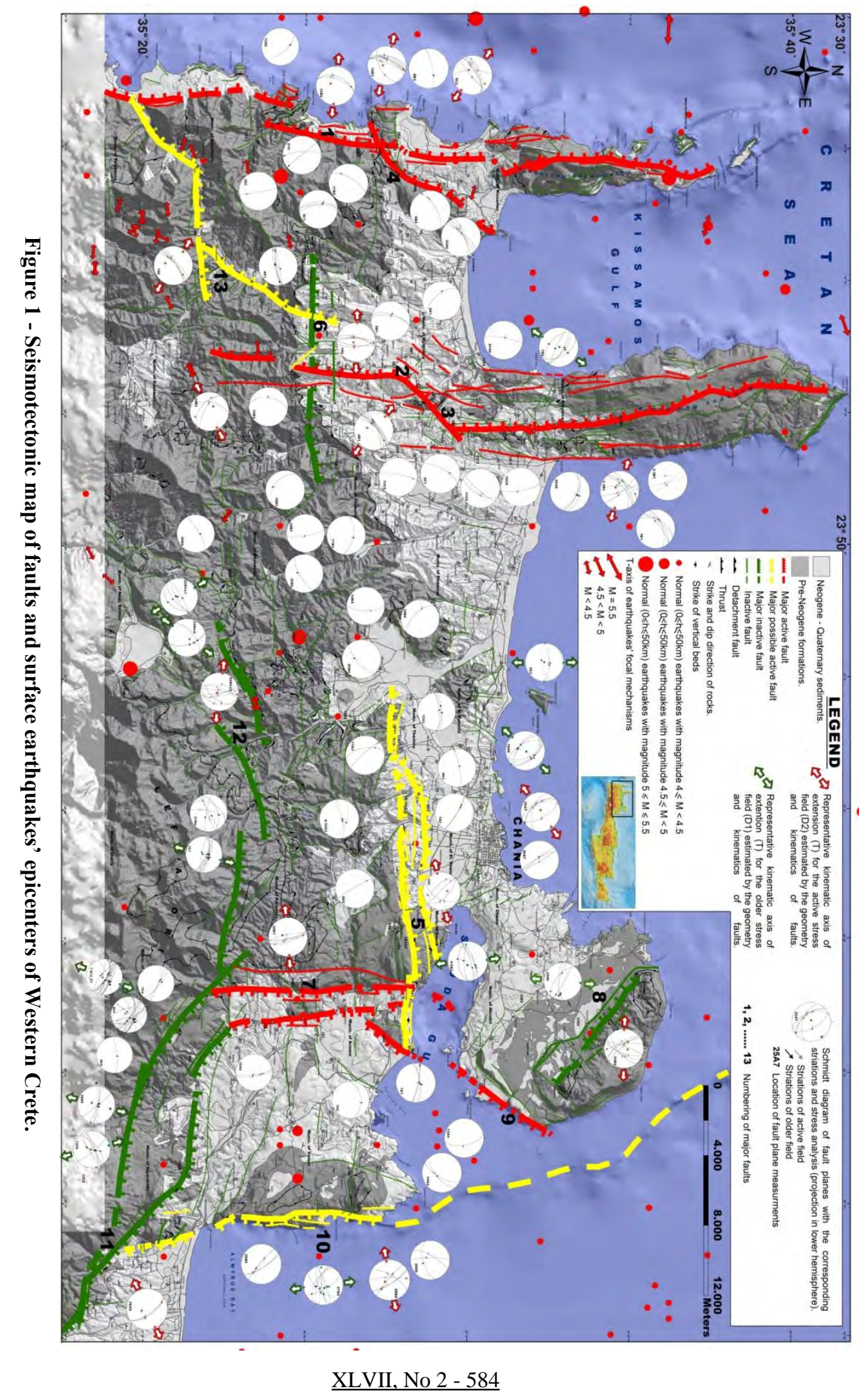


in W. Crete the basins of Souda-Mournies-Agia and Georgioupoli-Vryses-Pemonia. Essentially, they represent the stage immediately following the initial Miocene expansion collapse of the nappes pile along low angle normal detachment faults, with both events showing the same dynamics and kinematics. Our results are compatible with those of the Veen \& Postma (1999) for Central Crete.

The kinematic analysis of the $\mathrm{D}_{1}$ faults shows that their fault planes present high angle dip-slip striations, dipping mostly towards the NNE to NNW. The NNW slip motion corresponds to the relatively younger one of the $\mathrm{D}_{1}$ phase. Moreover, minor oblique normal faults trending NW-SE and NE-SW are also related to the $\mathrm{D}_{1}$ kinematics, showing significant sinistral or dextral horizontal component of motion, respectively. Paleostress analysis for the $\mathrm{D}_{1}$ event, using the inverse method of Angelier et al. (1982) and P-T method (Turner 1953), shows a low dipping angle minimum $\sigma 3$-stress axis with a strike varying between NNE-SSW to NNW-SSE (fig. 2 \& 3) for both methodes. The program Stereonett (Duyster 2000) has been used for the graphical presentation of structural data.
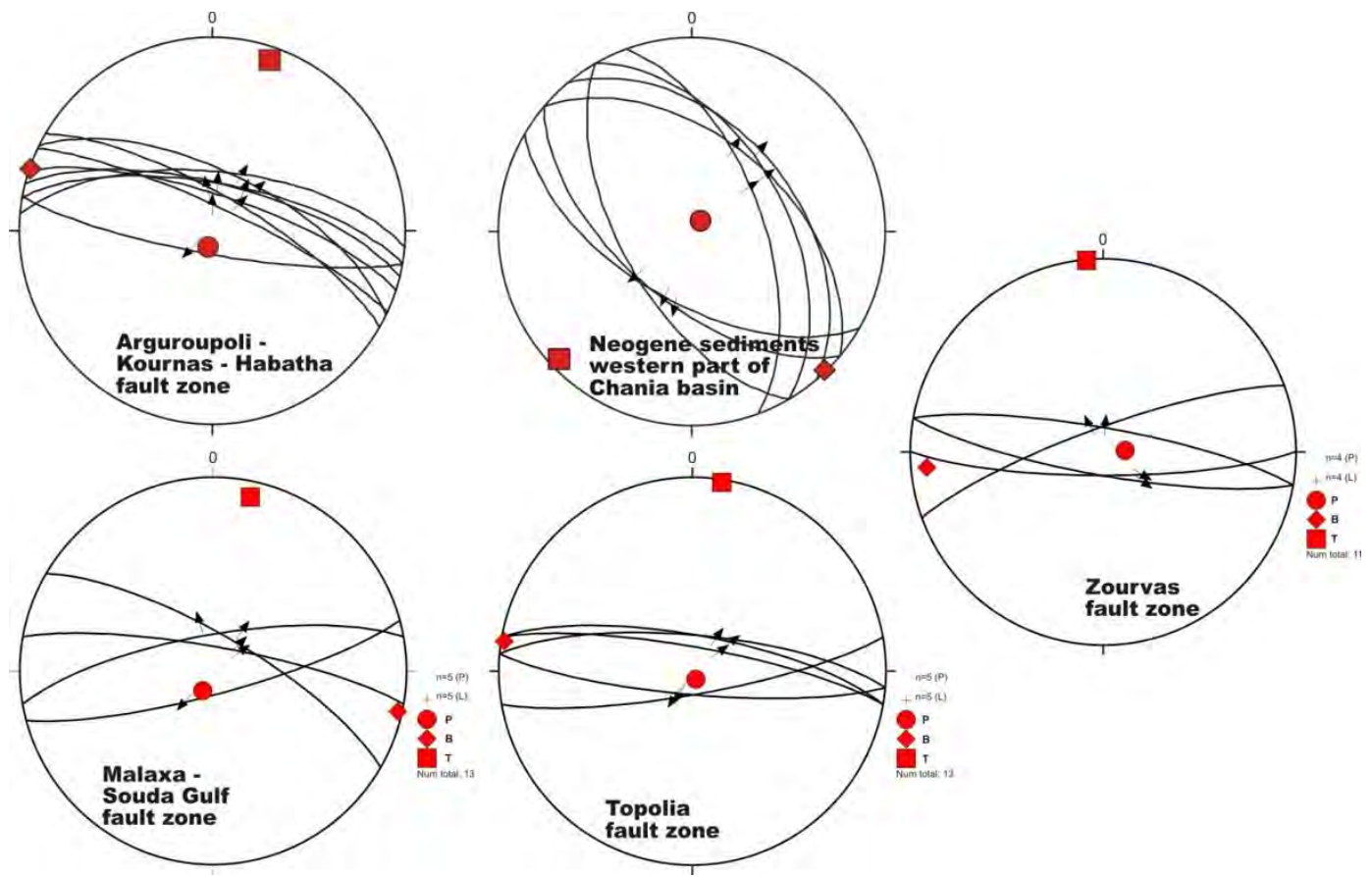

Figure 2 - Representative paleostress diagrams of $\sigma_{1}>\sigma_{2}>\sigma_{3}$ for the older $D_{1}$ event (lower hemisphere projection) by P-T method (Turner 1953) (see text for explanation).

The second $\mathrm{D}_{2}$ tectonic event took place from Upper Pliocene up to present. Faults of this event overprint the previous $\mathrm{D}_{1}$ faults, affecting usually the cataclastic fabric along the $\mathrm{D}_{1}$ fault zones. The $\mathrm{D}_{2}$ faults clearly affect the Pliocene sediments and have also been detected in recent Quaternary deposits, so can be characterized as active faults. They have N-S strike, varying from NNW-SSE to NNE-SSW, mostly dipping towards West. Additionaly, faults of NE-SW strike (occasionally also of NW-SE strike) are also closely related to the $\mathrm{D}_{2}$ kinematics. These are oblique-normal faults with significant sinistral or dextral horizontal component of motion. Some of these faults seem to form major transitional rupture zones between segments of the dominant $\mathrm{N}$ $S$ faults. However, older $D_{1}$ striations are recognized on the fault surfaces of these $D_{2}$ phase oblique-normal faults, revealing a possible reactivation during $\mathrm{D}_{2}$ tectonics, though they were initially created during the $\mathrm{D} 1$ event. The $\mathrm{D}_{2}$ kinematics are also often imprinted on the older E-W $\mathrm{D}_{1}$-faults by their reactivation as sinistral strike-slip faults, as can be derived from the horizontal 
striations on their fault surface. Paleostress analysis for the $\mathrm{D}_{2}$ tectonic event using the same methods shows a sub-horizontal minimum $\sigma_{3}$-stress axis, with strike ranging from WSW-ENE to WNW-ESE, with the second stress direction being the younger one. This pattern is in agreement with the active stress field along a narrow zone lying between the external NW-SW compression (due to the Eastern Mediterranean subduction under the Aegean) and the inner, back-arc $\sim \mathrm{N}-\mathrm{S}$ extension (e.g. Papazachos et al 1992). This narrow zone extends all the way from the AlbaniaGreece border and the main body of the Hellenides mountain chain up to Peloponnesus, Crete and Rhodes, following the shape of the Hellenic arc. However, its exact spatial extent is not clearly defined, since it locally exhibits partial overlapping, especially with the N-S extension area, e.g. in W. Macedonia and Epirus (Mountrakis et al., 2006).

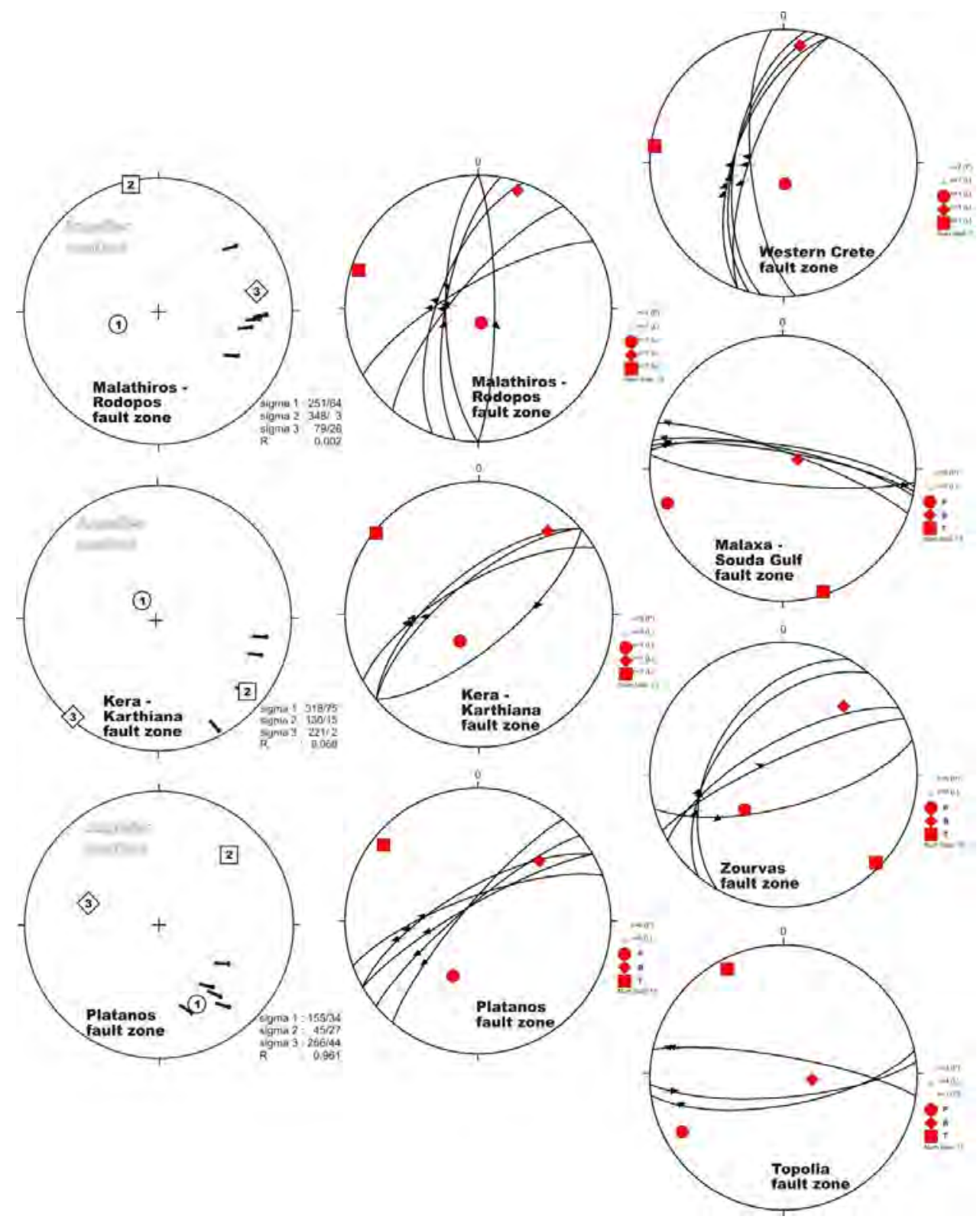

Figure 3 - Representative paleostress diagrams $\sigma_{1}>\sigma_{2}>\sigma_{3}$ for the $D_{2}$ event by Angelier et al. (1982) inverse method and P-T method (Turner 1953).

$\underline{\text { XLVII, No } 2-586}$ 
Correlating the active faults of the $\mathrm{D}_{2}$ event with the available fault plane solutions of the historical-recent earthquakes $(\mathrm{M} \geq 4.5)$ in the broader study area, a very good agreement is identified, both suggesting a E-W extension regime in NW Crete mainland. The determined fault plane solutions, published by Harvad, INGV, ETH and a large number of publications, suggest a distribution of the sub-horizontal $\left(\operatorname{dip}<30^{\circ}\right)$ principal stress axes in a consistent setting presented in figure (4). This distribution shows a clear separation of the outer arc NE-SW compression from the E-W extension regime in the NW Crete and the Kythira Island area.

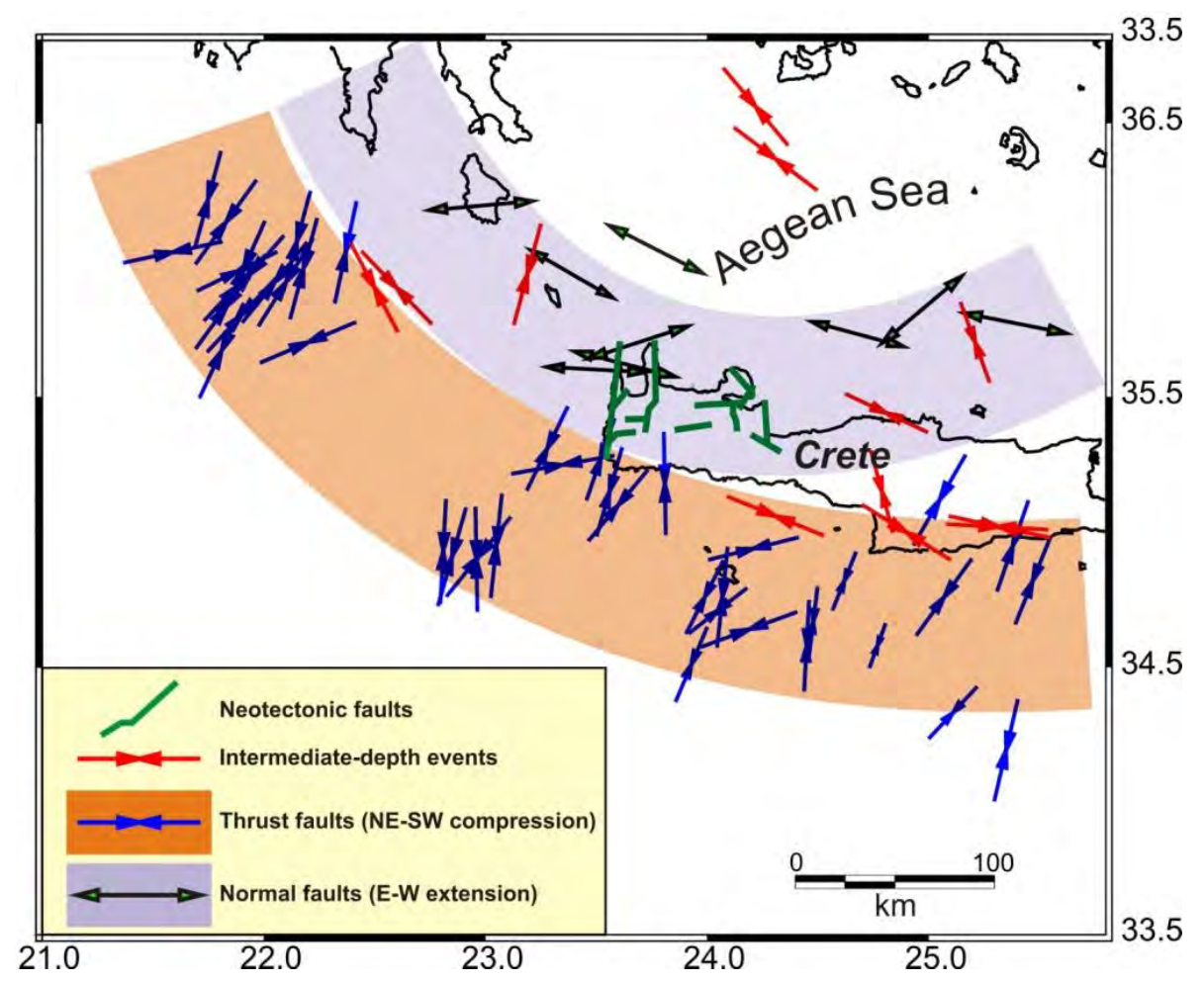

Figure 4 - Spatial distribution of the corresponding principal axes along the SW Hellenic arc, showing the clear separation of the compression area in the outer arc, with the $E-W$ extension area along the NW Crete-Kythira area. Regional focal mechanisms, compiled from several published sources, corresponding to thrust faults along the outer Hellenic arc, intermediate-depth, strike-slip fault, with significant thrust component and normal faults have been taken into account. Intermediate-depth events exhibit a typical slab-parallel compression. The main faults mapped in this study are schematically depicted with green lines.

In order to further examine this issue, we have also collected additional fault plane solutions determined from local temporary networks installed in W. Crete or the broader area (Besnard, 1991; Chabalier et al., 1992; Hatzfeld et al., 1993; Jost et al., 2002). The corresponding distribution is presented in fig. (5a), including mainly small events with $\mathrm{M}$ in the range -0.2 to 3.8 . The corresponding principal sub-horizontal extension axes distribution is quite consistent (fig. 5b), showing a dominant E-W extension. Using the resulting distribution, an average $\sigma_{3}$ extension axis was determined using the stress-tensor inversion method of Gephart and Forsyth (1984) and the average moment-tensor method of Papazachos and Kiratzi (1992). These results, also presented in fig. (5b), verify: a) The presence of an active E-W to WNW-ESE extension in W. Crete (compatible with the $\mathrm{D}_{2}$ phase recognized from active faulting) and, b) the spatial extent of the extension regime, which covers the whole $\mathrm{W}$. Crete mainland, showing that the $\mathrm{E}-\mathrm{W}$ extension controls the upper crustal deformation pattern throughout the whole study area. 


\section{Active Faults Seismic Hazard Assessment}

The $\mathrm{D}_{2}$ major normal faults of N-S strike are compatible with the active stress-field of E-W strike and certainly display clear indications of recent activity on the basis commonly accepted geological criteria, hence they were considered as active or possible active faults. Even more some of the $\mathrm{D}_{1}$ major normal faults of E-W or ENE-WSW strike, which are not optimally oriented with respect to the active stress-field, display indications of recent activity, operating as strike-slip faults, with the earthquake information being compatible with the strike E-W of some $\mathrm{D}_{1}$-faults mapped in the field. These results verify that some of the major normal E-W trending faults of the $\mathrm{D}_{1}$-phase reactivated as strike-slip faults under the E-W extensional regime of $\mathrm{D}_{2}$ phase even in recent times. Thus finally, in W. Crete 13 major faults were identified, which exhibit clear activation or reactivation in Quaternary-recent times (Mountrakis et al., 2012). These faults numbered 1 to 13 in the seismotectonic map (fig. 1) and were distinguished as active or possible active faults. Their seismic potential was assessed on the basis of the relation $\log \mathrm{L}=0.51 * \mathrm{M}-1.85$ (Papazachos 1989) relating the moment magnitude, $\mathrm{M}$, of the maximum expected earthquake with the total length, $\mathrm{L}$, of the fault. These most important faults in W. Crete are the following:

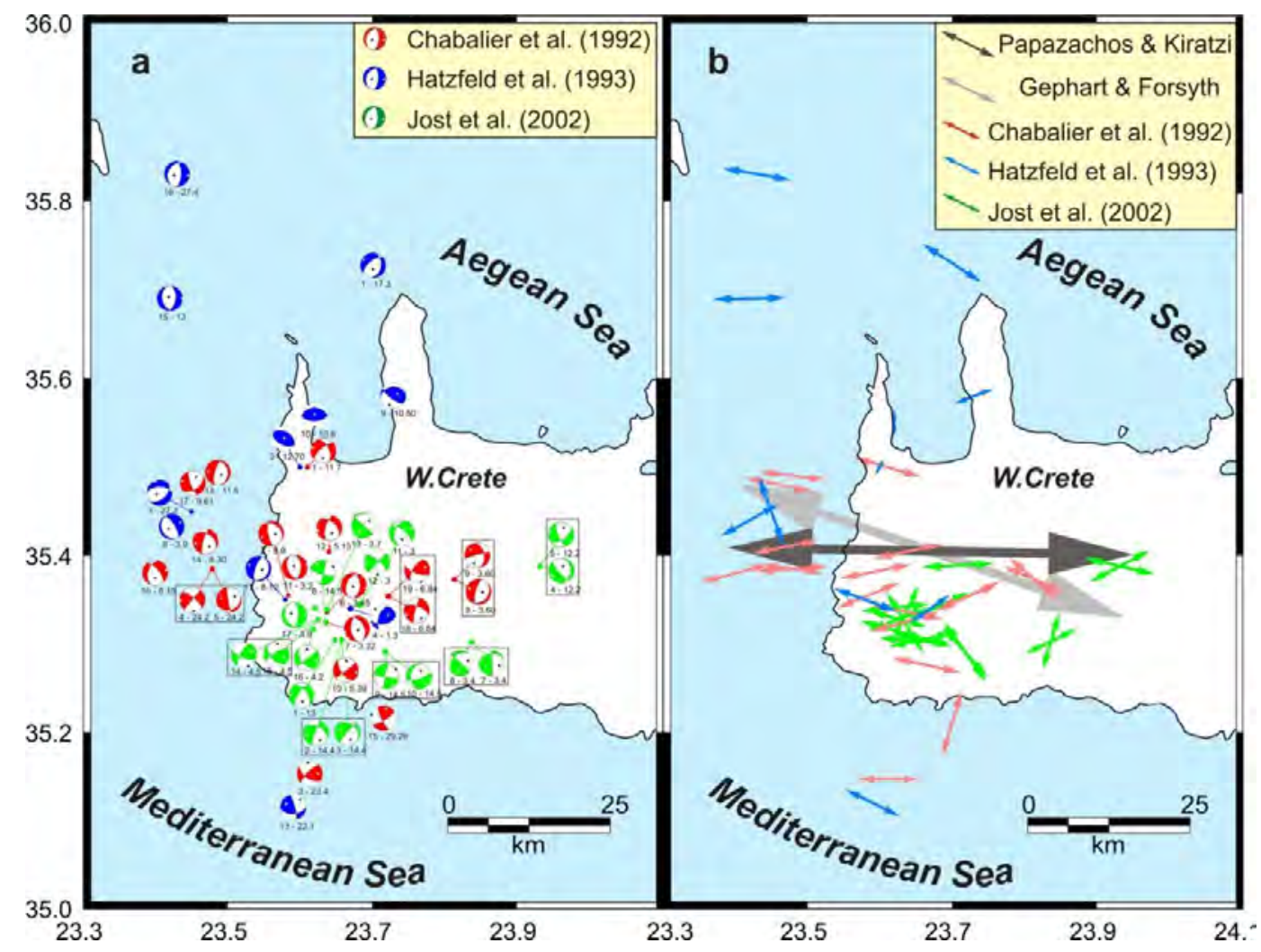

Figure 5 - a) Fault plane solutions for small-magnitude events in Western Crete. b) Spatial distribution of the corresponding principal extension axes. The average stress, computed with the methods of Gephart and Forsyth (1984) and Papazachos and Kiratzi (1992) are also presented with large grey and black arrows respectively.

1. The fault of Western Crete is an active rupture zone with a total length of $65 \mathrm{~km}$ and a N-S strike, dipping to the west. Its maximum expected earthquake magnitute is $M=7.2$. However the fault is displaying a spatial segmentation, probably suggesting its segmented activation with events of $M=5.6$ to 5.7 according to the partly length of the segments Gramvousa $(11 \mathrm{~km})$, FalasarnaSfinari $(11 \mathrm{~km})$ and Kampos-Stomion $(10 \mathrm{~km})$. 2. The fault of Malathiros-Rodopos is also a 
large $(30 \mathrm{~km})$ active fault zone (trend N-S, dip W), composed by three main segments: the Rodopos $(18 \mathrm{~km})$, Malathyros $(9 \mathrm{~km})$ and Kera $(4 \mathrm{~km})$. The last represents a rather dextral transfer fault between the other two segments. The maximum expected earthquake magnitude is 6.5, while the segmented activation corresponds to magnitudes M-6,1 and 5.5 respectively. 3. The Kera-Karthiana transfer active fault between the Malathiros-Rodopos segments, trends NE-SW and dips to NW. Its maximum expected earthquake magnitute is $M=5.0$. 4. The fault of Platanos (trend NE-SW, dip NW) overprints the Western Crete fault. It's characterized as a lateral-normal active fault with a significant sinistral horizontal component of motion. Its total length $\sim 10 \mathrm{~km}$ corresponds to a maximum magnitude of $\mathrm{M}=5.6$ with its sub-segments resulting of $\mathrm{M}=5.2$ and 4.8. 5. The Malaxa-Souda's Gulf possibly active fault is a rupture zone, (E-W strike, dip N) which forms the tectonic graben of Souda's Gulf-Mournies-Myloniana. Two main slip patterns were observed on the fault surfaces: The older one corresponds to a dip-slip motion, linked to the $\mathrm{D}_{1}$ extension and the younger to a mainly sinistral horizontal strike-slip motion related to the $\mathrm{D}_{2}$ extensional event. The length of the fault $(22 \mathrm{~km})$ corresponds to a maximum magnitude of $\mathrm{M}=6.2$. 6. The Topolia fault zone of $10 \mathrm{~km}$ length (trend $\mathrm{E}-\mathrm{W}$, dip $\mathrm{N}$ ) is related to the $\mathrm{D}_{1}$ event. However, younger striations on its fault surfaces show an important strtike-slip motion compatible to $\mathrm{D}_{2}$ kinematics of $\mathrm{U}$. Pliocene-Quaternary times. 7. The Zacharias-Pemonia active fault, (trend N-S, dip E) is composed by a system of parallel fault brances, successive tectonic terraces, and surface openings. Its total length is $11 \mathrm{~km}$, resulting in a maximum magnitude of $\mathrm{M}=5.7$. 8. The Akrotiri fault zone (trend NW-SE, dip SW) is composed by pallel faults in a characteristic "doublex" structure. The kinematics of the fault (oblique downwards sense of slip) indicate that it was activated during $\mathrm{D}_{2}$ event. 9. The Marathi active fault (trend NE-SW, dip SE) continues beyond Souda's Gulf and is also recognized in the Ancient Aptera archaeological site. Its length $(\sim 12 \mathrm{~km})$ corresponds to a maximum magnitude $\mathrm{M}=5.7$. 10. The Drepanokefala - Georgioupoli possibly active fault zone, (trend N-S, dip E) is composed by parallel fault segments, has a total length of $\sim 12 \mathrm{~km}$ corresponding to a maximum magnitude $\mathrm{M}=5.8$. 11. The ArgiroupoliKournas-Habathas fault zone, (trend NW-SE, dip NE) has a total length of $20 \mathrm{~km}$. Two slip patterns were observed on its fault planes: the first corresponds to the $\mathrm{D}_{1}$ event and the second to a strike-slip motion of the fault's reactivation during the $\mathrm{D}_{2}$ event in U. Pliocene-Quaternary times. 12. The Zourva fault (trend $\mathrm{E}-\mathrm{W}$, dip N) crosses the whole Western Crete. It is related to the Miocene extensional detachment of the nappes, but has been also activated during the $\mathrm{D}_{1}$ event with dip-slip motion towards the North as well as during the $\mathrm{D}_{2}$ event with a strike-slip component and a lateral sinistral sence of shear. Though it is not optimally oriented with respect to the active stress-field, the earthquake information be compatible with the strike of the Zourba fault. 13. The Xiropotamos-Elos-Myloi fault zone (trend NE-SW, dip NW) is composed of three continuous segments and it is compatible with active stress field. More over, small magnitude seismicity along all segments of the zone is recorded. Expected earthquake magnitude $M=5.5$ for its largest segment.

For further correlation of the mapped faults with the seismicity, we have grouped all fault plane solution data in a elliptical region around each of the 13 main faults and computed average fault plane solutions using the method of Papazachos and Kiratzi (1992), and the same approach has been adopted for the neotectonic information. The results are shown in figure (6), where we present both earthquake and neotectonic information as equivalent fault plane solutions for three faults or group of faults (No 1, 2-3, 12.). The results verify the excellent agreement of neotectonic and earthquake information. The neotectonic and seismological information was used in order to perform a quatitative assessment of seismic hazard for the study area. For this reason we used all the available historical and instrumental seismicity information in order to assign appropriate quantitative seismicity measures to the previously described faults, as well as to the major thrust fault of Elafonissos that generated the $365 \mathrm{BC} M=8.3$ earthquake (Papazachos 1990), which belong to the NE-SW compression area SW of Crete. 
For the historical seismicity information we mostly relied on the catalogue of Papazachos and Papazachou (2003), whereas instrumental seismicity information was based on the catalogue of the Geophysical Lab. of the Aristotle University of Thessaloniki which reports original or converted (equivalent) moment magnitudes for all events, up to 2009. The seismological information was used to determine the catalogue completeness from the Gutenberg-Richter curve and plots of the cumulative number of earthquakes versus time for several minimum magnitudes. The finally determined completeness for the W. Crete area was defined as: 1981-2002 $\mathrm{M} \geq 3.5$; 1964$2002 \mathrm{M} \geq 4.0 ; 1950-2002 \mathrm{M} \geq 4.5$. Using this completeness and the neotectonic and seismological information, we estimated appropriate seismicity parameters using elliptical areas around each of the 13 faults. Furthermore we considered the major thrust fault of Elafonissos, which strongly influences the seismic hazard assessment in the broader W. Crete area, and we also estimated the corresponding seismicity parameters for this fault. For all other areas outside the W. Crete we adopted the seismicity parameters of the zonation model proposed by Papaioannou and Papazachos (2000).

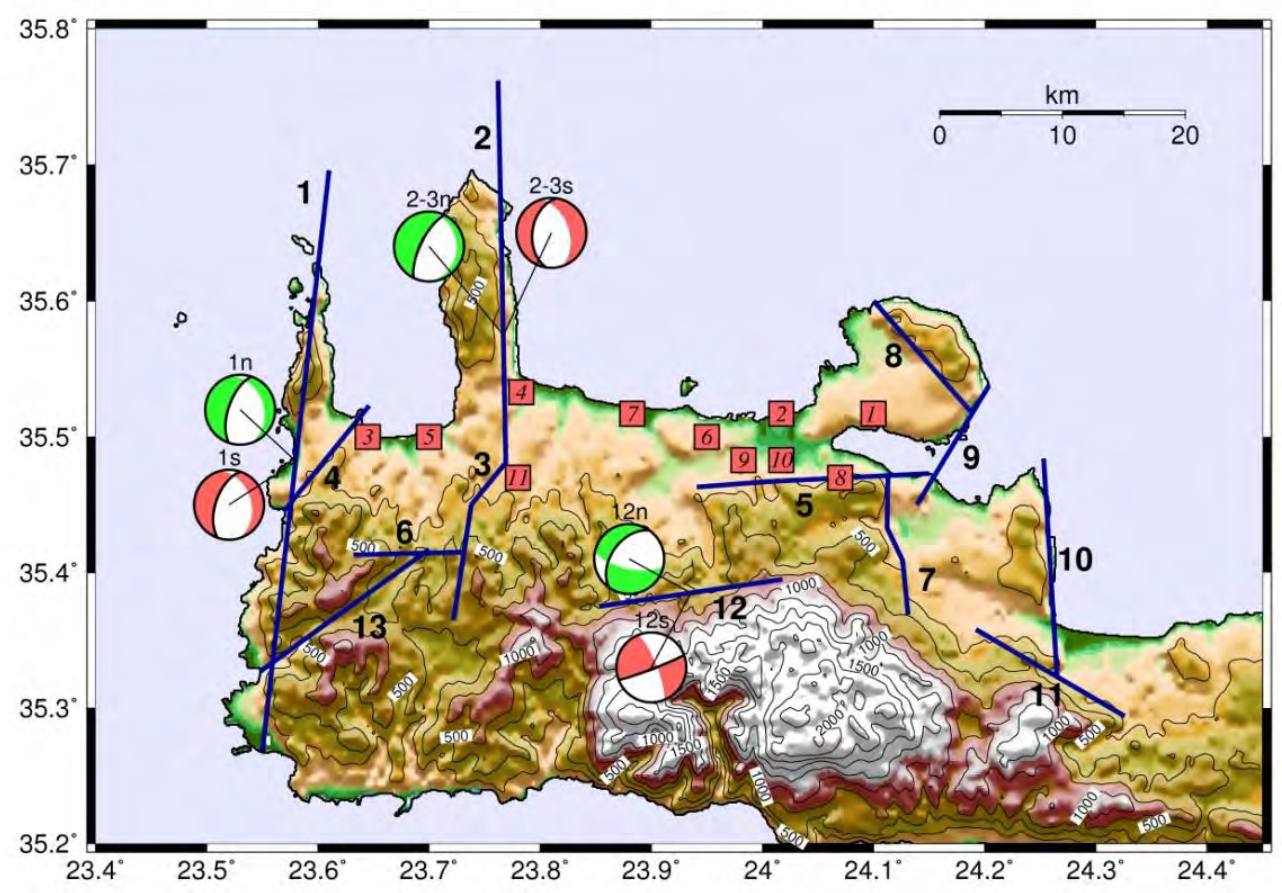

Figure 6 - Average fault plane solutions computed using the method of Papazachos and Kiratzi (1992) for faults 1 (W. Crete), 2-3 (Malathiros-Rodopos and Kera-Karthiana) and 12 (Zourva), from the available earthquake fault plane solution data (pink colored average solutions), as well as the corresponding neotectonic information from field observations (green colored average solutions). The main fault-plane is depicted with a thick line (see text for explanations). Red squares correspond to selected municipality centers for which seismic hazard analysis was performed (1:Akrotiri, 2: Chania, 3: Kissamos, 4: Kolymvari, 5: Mythimna, 6: N.Kydonia, 7: Platanias, 8: Souda, 9: Therissos, 10: Venizelos, 11: Voukolies).

In order to perform the final seismic hazard estimations we employed the PGA attenuation relation of Margaris et al. (2001) for shallow earthquakes and the relations of Theodulidis and Papazachos (1990) for intermediate-depth events. Seismic hazard estimations were performed using the Frisk88M (1995) code, appropriately modified in order to account for the different attenuation relations between shallow and intermediate-depth events, as well as anisotropic radiation of 
seismic energy at the source. Moreover, pseudo-velocity response spectra PSV(T) (in $\mathrm{cm} / \mathrm{sec})$ were also computed using the relations of Theodulidis and Papazachos (1994). Estimations were performed for 11 selected major sites, corresponding to the main municipalities (fig. 6). Seismic hazard results were computed for a $10 \%$ probability exceedence in $50 \mathrm{yr}$ (return period of $476 \mathrm{yr}$ ). In fig. 7 the results for 4 sites are presented. The sites have been selected in order to observe the gradual variation of the obtained seismic hazard results, as we move from the eastern (lower seismicity) to the westernmost (higher seismicity) part of the examined area. The results show higher seismic hazard levels for the Kissamos site, as it is affected by seismicity of the major neighboring Western Crete fault. On the other hand, the Kolymvari site exhibits quite low seismic hazard levels, despite being close to the neighboring active faults (Malathyro-Rodopos and KeraKarthiana faults). The results verify the spatial variability of seismic hazard, suggesting that the identified active faults have an important effect on the seismic hazard assessment.

In order to quantify the effect of the seismotectonic model on the seismic hazard assessment, appropriate deaggregation of the seismic hazard results was performed for each examined site and all seismic sources affecting this site. The earthquake scenario were considered as design earthquakes and used in a stochastic simulation procedure, in order to estimate the contribution of each fault on the seismic hazard of each site, employing the methodology of Beresnev and Atkinson (1997). Using the stochastic simulation, average elastic response spectra (for 5\% damping and amplification factor of $\beta_{0}=2.5$ ) were computed using a large number of simulations (typically 30) for each site. Sample results are presented in fig. (8) for the same sites as in fig. (7).
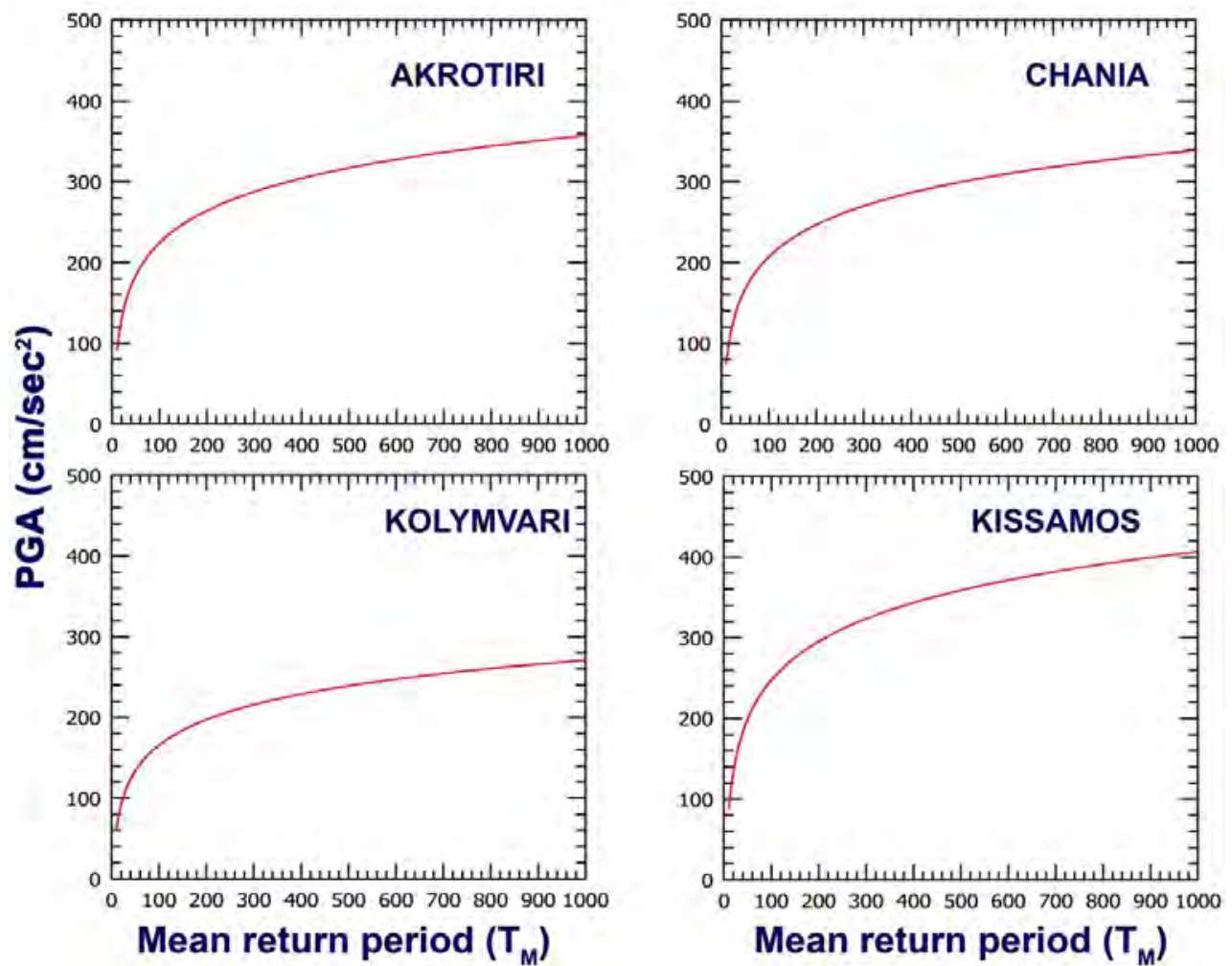

Figure 7 - Seismic hazard curves for the municipalities of Akrotiri, Chania, Kolymvari and Kissamos.

Moreover, the probabilistic elastic response spectra as determined from the initial seismic hazard analysis for two site conditions (rock and stiff soil), as well as the Greek Seismic Code (NEAK) elastic design spectra are also presented for all sites. The results additionaly confirm the strong 
spatial variability of the seismic hazard in the western Crete. For sites located in the eastern (lower seismicity) part of the study area (Akrotiri, Chania) the NEAK elastic response spectra cover the probabilistic estimates from the hazard analysis. Moreover, the main contribution in seismic hazard is due to the Elafonisos thrust fault, which is almost identical to the probabilistic estimate, suggesting that the contribution of the active but low-seismicity neighboring neotectonic faults (faults $5,7,8$, etc.) is minimal and that the main source of seismic hazard for these sites is the large thrust events that originate from the outer Hellenic arc convergence zone. A quite different situation holds for sites located in the western part of the study area. Compared to the Seismic Code design spectra, the probabilistic elastic spectra are slightly larger (up to $0.9 \mathrm{~g}$ ) at higher frequencies $(2-10 \mathrm{~Hz})$ for Kolymvari and much larger (up to $1.45 \mathrm{~g}$ ) for frequency range (1.2 $-20 \mathrm{~Hz}$ ) for the Kissamos site, suggesting that the Seismic Code spectra probably need adapting, especially for the Kissamos site. Even more important is the pattern change regarding the seismic hazard source contributions: For the Kolymvari site the contribution of the Elafonisos thrust fault is comparable to the contribution of the neighboring active Malathyros-Rodopos fault (fault 2), especially for higher frequencies (lower periods). This pattern is even more enhanced for the Kissamos site, where the neighboring faults of Western Crete (1) and Platanos (4) control the seismic hazard, while the Hellenic arc thrust fault contribution is significantly reliable smaller. This result further verifies the importance for the detailed neotectonic mapping for seismic hazard assessment.
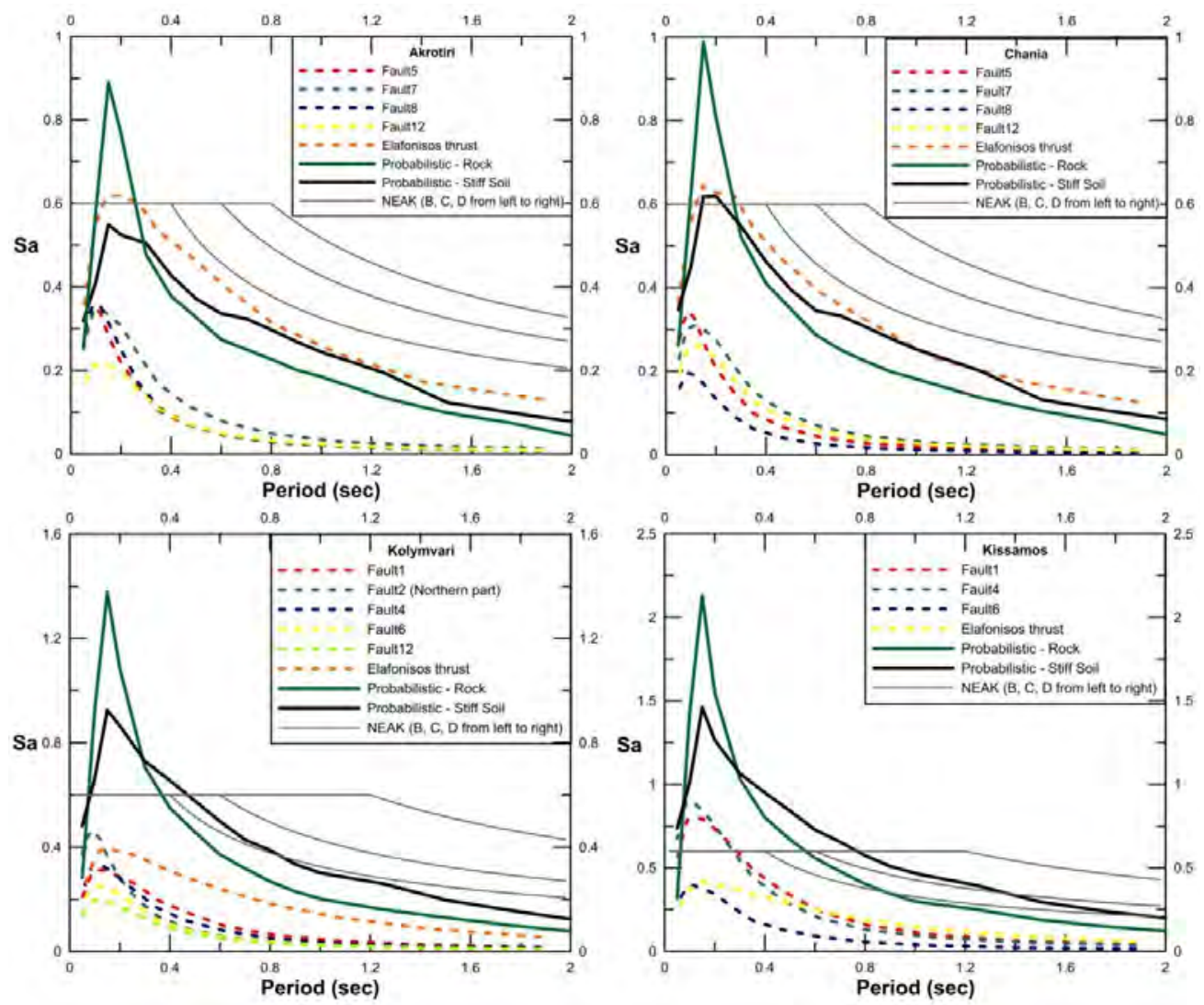

Figure 8 - Comparison of stochastic simulation elastic response spectra from the deaggregation analysis with the corresponding probabilistic elastic spectra from seismic hazard assesment and the Greek Seismic Code (NEAK) elastic response spectra for the municipalities of Akrotiri, Chania, Kolymvari and Kissamos. 


\section{Conclusions}

After the detailed neotectonic and seismotectonic analysis we conclude that two distinctive stress phases took place. The first one $\left(\mathrm{D}_{1}\right.$, Mid-Upper Miocene to Lower Pliocene) exhibits a N-S extension and was responsible for the formation of the dominant $\mathrm{E}-\mathrm{W}$ trending normal faults that control the shape of the large Neogene basins of Western Crete. The second one $\left(\mathrm{D}_{2}\right.$, Lower Pliocene to present) exhibits a E-W extension, forming mainly N-S faults, but also NE-SW trending smaller faults with significant strike-slip component, often acting as transfer zones between the larger N-S fault zones. Additionaly, some E-W faults from the previous $\mathrm{D}_{1}$ phase are often reactivated, during the later $\mathrm{D}_{2}$ phase, as almost pure strike-slip faults. This pattern is in excellent agreement with the seismological information, that show mostly N-S normal fault mechanisms, as well as NW-SE and NE-SW strike-slip mechanisms with significant normal component. The determined active stress field from fault plane solution data also shows a dominant E-W extension, suggesting that the $\mathrm{D}_{2}$ phase identified by field data is an on-going active process.

Using a combination of field data and seismicity information, 13 large major fault zones were defined and characterized as active or possible active faults. They were incorporated in a detailed seismic hazard analysis, which also took into account the large thrust fault zones of the outer Hellenic arc, as well as the Benioff-zone intermediate-depth events. The probabilistic and a deterministic approach for seismic hazard evaluation, allowed not only the reliable estimation of the seismic hazard for several selected sites but also the effective deaggregation of the seismic hazard results. The seismic hazard of the westernmost part of study area is mainly controlled by the neighboring higher seismicity neotectonic faults, while the corresponding hazard of the central and easternmost part is mostly affected by the large outer arc thrust. Thus, the combined interpretation of field (neotectonic) data with seismological information is essential, not only for the better understanding of the ongoing seismotectonic processes but also for the efficient and reliable estimation of seismic hazard and the corresponding probabilistic or deterministic analysis.

\section{References}

Angelier J., Tarantola A., Valette B. and Manoussis S. 1982. Inversion of field data in fault tectonics to obtain the regional stress. Part I. Simple phase fault populations: a new method of computing the stress tensor, Geophys. J. R. Astr. Soc., 6, 607-621.

Beresnev I. and Atkinson G. 1997. Modeling finite-fault radiation from the $\omega$ n spectrum, Bull. Seism. Soc. Am., 87, 67-84.

Besnard M. 1991. Sismotectonique de l'arc egeen, resultants d'une campange de microsismicite, PhD. Thesis, Grenoble, France.

Bonneau M. 1984. Correlation of the Hellenic nappes in the southern Aegean and their tectonic reconstruction, In: The Geological Evolution of Eastern Mediterranean, ed. J. Dixon, \& A. Robertson, Geol. Soc. London, Sp. Publ., 17, 517-527.

Chabalier B., Lyon-Caen H., Zollo A., Deschamps A., Bernard P and Hatzfeld D. 1992. A detailed analysis of microearthquakes in western Crete from digital three-component seismograms. Geophys. J. Int., 110, 347-360.

Duyster J. 2000. Stereo Nett, Microsoft Corp., Universtität Bochum.

Fassoulas C., Kilias A. and Mountrakis D. 1994. Postnappe stacking extension and exhumation of HP/LT rocks in the island of Crete, Greece, Tectonics, 13, 127-138.

FRisk88M 1995. User's Manual, ver. 1.70, Risk Engineering Inc., Boulder Co., 69 pp.

Gephart J. and Forsyth D. 1984. An improved method for determining the regional stress tensor using earthquake focal mechanism data: Application to the San Fernando earthquake sequence, J. Geophys. Res., 89, 9305-9320.

Hatzfeld D., Besnard M., Makropoulos K. and Hatzidimitriou P. 1993. Microearthquake seismicity and fault plane solutions in the southern Aegean and its geodynamic implications, Geophys. J. Int., 115, 799-818. 
Jolivet L., Goffé B., Monie P., Truffert-Luxey C., Patriat M. and Bonneau M. 1996. Miocene detachment in Crete and exhumation P-T-t paths of high-pressure metamorphic rocks, Tectonics, 15, 1129-1153.

Jost L., Knabenbauer O., Cheng J. and Harjes H. 2002. Fault plane solutions of microearthquakes and small events in the Hellenic arc, Tectonophysics, 356, 87-114.

Kilias A., Fassoulas C. and Mountrakis D. 1994. Tertiary extension of continental crust and uplift of Psiloritis metamorphic core complex in the central part of the Hellenic Arc (Crete, Greece), Geol. Rundsch., 83, 417-430.

Kilias A, Frisch W., Avgerinas A., Dunkl I., Falalakis G. and Ganlick H. 2010. Alpine architecture and kinematics of deformation of the Northern Pelagonian nappe pile in the Hellenides, Austrian J. of Earth Sciences, 103, 4-28.

Margaris B., Papazachos C., Papaioannou C., Theodulidis N., Kalogeras I. and Skarlatoudis A. 2001. Empirical attenuation relations for strong horizontal seismic motion of shallow earthquakes in Greece, 2nd Hell. Con. of Earthq. Eng. and Eng. Seism., Vol.1, 27-36.

Mercier J., Sorel D., Vergely, P. and Simeakis K. 1989. Extensional tectonic regimes in the Aegean basins during the Cenozoic, Basin Res., 2, 49-71.

Mountrakis D. 2006. Tertiary and Quaternary tectonics of Greece, Geol. Soc. Amer. Bull., sp. Paper, 409, 125-136.

Mountrakis D., Tranos M., Papazachos C., Thomaidou E., Karagianni E. and Vamvakaris D. 2006. Neotectonic and seismological data concerning major active faults, and the stress regimes of Northern Greece. In: Robertson, A. \& Mountrakis, D. (eds). Tect. Devel. of East. Mediterranean, Geol. Soc. London, Sp. Publ., 260, 649-670.

Mountrakis, D., Kilias, A., Pavlaki, A., Fassoulas, C., Thomaidou, E., Papazachos, C., Papaioannou, C., Roumelioti, Z., Benetatos, C. and Vamvakaris D. 2012. Neotectonic study of the Western Crete. Seismic risk evaluation of the active faults, In: (Ed.) E. Skourtsos, and G. Lister, The Geology of Greece, Journal of the Virtual Explorer, Electronic Edition, ISSN 1441-8142, vol. 42, paper 4.

Papaioannou Ch. and Papazachos B. 2000. Time-independent and time-dependent seismic hazard in Greece based on seismogenic sources, Bull. Seism. Soc. Am., 90, 22-33.

Papazachos B. 1989. A time predictable model for earthquake generation in Greece, Bull. Seism. Soc. Am., 79, 77-84.

Papazachos B. 1990. Seismicity of the Aegean and surrounding area, Tectonophysics, 178,287-308.

Papazachos B., Karakostas V., Papazachos C. and Scordilis E. 2000. The geometry of the WadatiBenioff zone and lithospheric kinematics in the Hellenic arc, Tectonophysics, 319, 275-300.

Papazachos B. and Papazachou C. 2003. The earthquakes of Greece, 3rd Edition, Ziti Publ., Thessaloniki, $273 \mathrm{pp}$.

Papazachos C. and Kiratzi A. 1992. A formulation for reliable estimation of active crustal deformation and its application to central Greece, Geophys. J. Int., 111, 424-432.

Papazachos C., Kiratzi A. and Papazachos B. 1992. Rates of active crustal deformation in the Aegean and surrounding area, Journal of Geodynamics, 16, 147 -179.

Seidel E., Kreuzer H. and Harre W. 1982. A Late Oligocene/Early Miocene high pressure belt in the external Hellenides, Geol. Jahrb., E 23, 165-206.

TenVeen, J. and Postma G. 1999. Roll-back controlled vertical movements of outer-arc basins of the Hellenic subduction zone (Crete, Greece), Basin Res., 11, 243-266.

Theodulidis N. and Papazachos B. 1990. Strong motion from intermediate depth subduction earthquakes and its comparison with that of shallow earthquakes in Greece, Proc. XXII Gen. Assembly ESC, Barcelona, II, 857-864.

Theodulidis N. and Papazachos B. 1994. Dependence of strong ground motion on magnitudedistance, site geology and macroseismic intensity for shallow earthquakes in Greece: II, Peak horizontal pseudovelocity, Soil Dyn.Earth. Eng., 13, 317-343.

Turner F. 1953. Nature and dynamic interpretation of deformation lamellae in calcite of three marbles, Am. J. Sci., 4, 276-298.

$\underline{\text { XLVII, No } 2-594}$ 